\title{
Induction of CD95 ligand and apoptosis by doxorubicin is modulated by the redox state in chemosensitive- and drug-resistant tumor cells
}

\author{
Claudia Friesen ${ }^{1}$, Simone Fulda ${ }^{1}$ and \\ Klaus-Michael Debatin*,1,2 \\ 1 University Children's Hospital, Prittwitzstr.43, 89075 UIm, Germany \\ 2 Division of Molecular Oncology, German Cancer Research Center, Im \\ Neuenheimer Feld 280, D-69120 Heidelberg, Germany \\ * corresponding author: Prof. Dr. Klaus-Michael Debatin, University Children's \\ Hospital, Prittwitzstr. 43, D-89075 ULM, Germany. tel: +49-731-5027700; \\ fax. +49-731-5026681
}

Received 24.11.98; revised 16.2.99; accepted 22.2.99

Edited by A. Finazzi-Agró

\begin{abstract}
Induction of CD95 ligand (CD95-L) may contribute to druginduced apoptosis in chemosensitive leukemias and solid tumors. Here we report that induction of CD95-Land apoptosis by doxorubicin in leukemic and neuroblastoma cells is regulated by the redox state and reactive oxygen species (ROS). Preincubation of chemosensitive cells with antioxidants such as $\mathrm{N}$-acetyl-cysteine (NAC) or glutathione (GSH), significantly reduced doxorubicin-induced apoptosis, hyperexpression of ROS, loss of mitochondrial membrane potential $\left(\Delta \Psi_{m}\right)$ and upregulation of CD95-L expression. Doxorubicinresistant cells exhibited higher levels of GSH in comparison to chemosensitive cells and were deficient in hyperproduction of $\mathrm{ROS}$, loss of $\Delta \Psi_{\mathrm{m}}$ and upregulation of CD95-L in response to cytotoxic drugs. Downregulation of intracellular GSH concentrations reversed deficient drug-induced hyperproduction of ROS and CD95-L upregulation. In addition, overexpression of $B c I-X_{L}$ in CEM cells blocked doxorubicin-triggered ROS and CD95-L expression. These findings suggest that induction of CD95-L by cytotoxic drugs is modulated by the cellular redox state and mitochondria derived ROS.
\end{abstract}

Keywords: apoptosis; CD95 ligand; glutathione; doxorubicin; mitochondria; redox state

Abbreviations: $\mathrm{AA}$, ascorbic acid; $\mathrm{AICD}$, activation-induced cell death; BSO, L-buthionine-(S,R)-sulfoximine, CAT, catalase; CD95L, CD95-ligand; CD95, CD95 receptor; CHX, cycloheximide; $\mathrm{DiOC}_{6}(3), 3,3^{\prime}$-dihexyloxacarbocyanine iodide; DOXO, doxorubicin; DOXOR, doxorubicin-resistant; $\Delta \Psi_{\mathrm{m}}$, mitochondrial membrane potential; FSC, forward scatter; GSH, glutathione; HE, dihydroethidine; $\mathrm{mBCl}$, monochlorobimane; MRP, multi-drug resistant protein; NAC, N-acetylcysteine; NGF, nerve growth factor; P-gp, $p$ glycoprotein; PARP, poly(ADP-ribose)polymerase; PI, propidium iodide; PT, permeability transition; ROS, reactive oxygen species; SOD, superoxide dismutase; SSC, side scatter

\section{Introduction}

Most anticancer drugs have been found to induce apoptosis in chemosensitive leukemias and solid tumors. ${ }^{1,2}$ The CD95 receptor/CD95 ligand (CD95/CD95-L) system is a key signal pathway involved in regulation of apoptosis in several cell types. ${ }^{3-7}$ The CD95 cell surface receptor (CD95) is a member of the tumor necrosis factor/nerve growth factor (TNF/NGF) receptor superfamily of cell surface molecules which mediates apoptosis upon oligomerization. ${ }^{8-13}$ CD95 crosslinking by agonistic antibodies or the natural ligand activates a signal cascade via FADD/MORT-1 and FLICE/MACH that directly leads to activation of ICE/Ced-3 proteases (caspases) which function as downstream effectors of cell death. ${ }^{14}$ The CD95 ligand (CD95-L) is a member of the corresponding family of TNF-related cytokines, which is found in a soluble or membrane-bound form. CD95-L may cause autocrine suicide in sensitive $\mathrm{CD}^{+} 5^{+} \mathrm{T}$-cells and fracticide or paracrine death in neighboring T-cells or other target cells. ${ }^{15-17}$

Induction of CD95-L and upregulation of CD95 has been found after treatment of tumor cells with cytotoxic drugs. ${ }^{18-25}$ Blocking of CD95/CD95-L interaction by antagonistic antibodies to the receptor downregulates drug-induced apoptosis. ${ }^{18,21-23,25,26}$ Activation of the CD95 system has been observed in a variety of different tumor cell lines such as hepatoma, ${ }^{23}$ neuroblastoma, ${ }^{21}$ colon carcinoma ${ }^{24}$ and medulloblastoma ${ }^{22}$ and in ex vivo derived tumor cells ${ }^{19}$ with different drugs, such as doxorubicin, ${ }^{18,19,21}$ cisplatin, ${ }^{21}$ etoposide ${ }^{21,25}$ teniposide, ${ }^{25}$ cytarabine, ${ }^{19}$ fluorouracil, ${ }^{24}$ bleomycin ${ }^{23}$ and methotrexate $^{18,19}$ although the relative contribution of CD95/CD95-L interaction is controversial. ${ }^{27-33}$ Several recent reports have indicated that mitochondria play a major role in apoptosis including cell death induced by anticancer agents. ${ }^{34-38} \mathrm{~A}$ crucial, common step in most forms of apoptosis involves a loss of mitochondrial membrane potential $\left(\Delta \Psi_{\mathrm{m}}\right)$. Disruption of $\Delta \Psi_{\mathrm{m}}$ is mediated by opening of permeability transition (PT) pores resulting in hyperproduction of reactive oxygen species (ROS). Overexpression of ROS-scavenging enzymes and various antioxidants with ROS-scavenger properties were reported to block apoptosis induced by tumor necrosis factor (TNF), anticancer drugs such as doxorubicin, ${ }^{39} \gamma$-irradiation and activation-induced cell death (AICD). ${ }^{40}$ Anti-apoptotic members of the Bcl-2 family have been shown to prevent apoptosis in response to a wide variety of apoptosis stimuli. Overexpression of $\mathrm{Bcl}-2$ or $\mathrm{Bcl}-$ $X_{L}$ prevents mitochondrial permeability transition and hyperproduction of ROS by different apoptosis inducing stimuli. ${ }^{34}$ Since some of these apoptosis inducers involve induction of CD95-L and activation of the CD95 system we investigated the role of the cellular redox state and ROS in drug-induced expression of CD95-L. 


\section{Results}

\section{Effects of NAC and GSH on doxorubicin-induced apoptosis}

Reduced glutathione (GSH, a cystein-containing tripeptide: L$\gamma$-glutamyl-L-cysteinyl-glycine), the most abundant intracellular thiol acts as a major antioxidant by protecting cells against damaging effects of free radicals and reactive oxygen species (ROS) and may protect cells from apoptotic cell death. ${ }^{41-46}$ We therefore examined whether an increase in intracellular GSH would also affect drug-induced apoptosis in a chemosensitive leukemia cell line (CEM) and chemosensitive neuroblastoma cell line (SHEP). Since $\mathrm{N}$-acetyl-cysteine (NAC) is known to increase intracellular GSH, ${ }^{42}$ we examined whether pretreatment with NAC or GSH could prevent doxorubicin-induced apoptosis. The leukemia cell line CEM and the neuroblastoma cell line SHEP were pretreated with NAC or GSH for $2 \mathrm{~h}$ before doxorubicin-treatment (Figure $1 \mathrm{~A}$ ). After $30 \mathrm{~h}$ for CEM and $72 \mathrm{~h}$ for SHEP a significant reduction of doxorubicin-induced apoptosis was found in both cell lines pretreated with NAC or GSH in comparison to non pretreated cells. The inhibitory effect of NAC was mediated by upregulation of intracellular GSH, since coincubation of CEM cells with NAC and BSO, a specific inhibitor for GSH synthesis, ${ }^{47}$ almost completely abolished the inhibitory effect of NAC (Figure 1B). We next investigated whether other nonthiol antioxidants with different ROS protecting effects such as catalase (CAT), superoxide dismutase (SOD) and ascorbic acid (AA) could also prevent doxorubicin-induced apoptosis. CEM cells were pretreated with catalase, superoxide dismutase or ascorbic acid $2 \mathrm{~h}$ before doxorubicin treatment. After $30 \mathrm{~h}$ a moderate protection against doxorubicinmediated apoptosis was found (Figure 1C). These data demonstrate that only GSH could significantly protect cells from doxorubicin-induced apoptosis.

\section{Effects of NAC and GSH on doxorubicin-induced $\Delta \Psi_{\mathrm{m}}$ reduction and $\mathrm{ROS}$ generation}

Mitochondrial function involving loss of membrane potential by opening of PT pores and hyperproduction of ROS has been implicated in cell death induced by anticancer drugs. $^{34,35}$ Since antioxidants have been shown to inhibit doxorubicin-mediated death we analyzed the effects of antioxidants on doxorubicin-induced mitochondrial dysfunction. Incubation of chemosensitive CEM cells with doxorubicin lead to disruption of $\Delta \Psi_{m}$ and hyperproduction of ROS at early time points. Disruption of $\Delta \Psi_{\mathrm{m}}$ and hyperproduction of ROS were significantly reduced when chemosensitive cell lines were pretreated with NAC or GSH before doxorubicin treatment (Figure 1D). These data suggest that NAC or GSH mediated inhibition of doxorubicin-induced apoptosis involves inhibition of disruption of $\Delta \Psi_{\mathrm{m}}$ and generation of ROS from mitochondria.

\section{Effects of NAC and GSH on drug-induced induction of CD95-L}

CD95- $L$ is produced in chemosensitive leukemias and solid tumors in response to drug treatment ${ }^{18-26}$ and deficient upregulation of CD95-L may contribute to drug-resistance of tumor cells. ${ }^{19}$ We therefore asked whether upregulation of CD95-L by cytotoxic drugs would be modulated by intracellular GSH concentrations. Incubation of chemosensitive cell lines CEM and SHEP cells with doxorubicin after pretreatment with NAC or GSH completely blocked upregulation of CD95-L mRNA as shown by reverse transcriptase polymerase chain reaction (RT-PCR) (Figure $2 \mathrm{~A}$ and $\mathrm{B}$ ). In addition, no drug-induced upregulation of CD95-L protein was observed as shown by Western blot analysis (Figure 2A). These results are in agreement with data recently published showing that bleomycininduced CD95-L mRNA involves ROS in hepatoma cells. $^{48}$ Furthermore, downregulation of CD95 expression was not found in chemosensitive cells after pretreatment with NAC or GSH at time points used in these experiments (data not shown). Defective activation of caspases by cytotoxic drugs after pretreatment with NAC or GSH was also reflected by the failure to cleave the prototype caspase substrate poly(ADP-ribose)polymerase (PARP). ${ }^{49}$ PARP was processed to its characteristic $85 \mathrm{kDa}$ fragment by doxorubicin in chemosensitive CEM and SHEP cells but not in chemosensitive cells pretreated with NAC or GSH before doxorubicin treatment (Figure 2C). To see whether differences in intracellular GSH concentrations would modulate chemosensitivity, we generated $\mathrm{CEM}^{\mathrm{DOXOR}}$ and SHEP DOXOR, variants of CEM or SHEP cells, resistant to therapeutic concentrations of doxorubicin for over 24 months. ${ }^{19}$ Both variants of resistant cells did not exhibit a multi drug-resistant (MDR) phenotype of drug-resistance since doxorubicin uptake was not altered in resistant cells as compared to sensitive parental cells. ${ }^{19}$ Cytofluorometric analysis using $\mathrm{mBCl}$ (monochlorobimane) ${ }^{44,45}$ for detection of intracellular GSH revealed higher GSH concentrations in doxorubicin-resistant cell lines compared to parental chemosensitive cell lines (Figure 3). These findings suggest that differences in intracellular GSH concentrations may modulate induction of CD95-L, full activation of the CD95 pathway and chemosensitivity.

\section{$\Delta \Psi_{\mathrm{m}}$ reduction and ROS generation in doxorubicin-resistant cells}

Since high GSH levels prevent cells from doxorubicin-induced loss of $\Delta \Psi_{\mathrm{m}}$ and ROS generation and since doxorubicinresistant cells show a higher concentration of GSH compared to chemosensitive cells, we asked whether disruption of $\Delta \Psi_{\mathrm{m}}$ and hyperproduction of ROS was also reduced in doxorubicin-resistant cells. In contrast to parental CEM cells, loss of $\Delta \Psi_{\mathrm{m}}$ and hyperproduction of ROS could not be detected in $\mathrm{CEM}^{\mathrm{DOXOR}}$ cells after drug treatment (Figure 4).

\section{Effect of Bcl- $X_{L}$ on activation of the CD95 system}

Since $\mathrm{Bcl}-\mathrm{X}_{\mathrm{L}}$ is located in mitochondria and prevents cells from doxorubicin-induced apoptosis and loss of $\Delta \Psi_{\mathrm{m}}$ and ROS generation ${ }^{34}$ (data not shown), we asked whether doxorubicin-induced CD95-L expression was modulated in $\mathrm{Bcl}-\mathrm{X}_{\mathrm{L}}$ transfected $\mathrm{CEM}$ cells $\left(\mathrm{CEM}^{\mathrm{Bcl}-\mathrm{XL}}\right)$. In contrast to parental CEM cells, no CD95-L upregula- 
tion was found in $\mathrm{Bcl}-\mathrm{X}_{\mathrm{L}}$ transfected $\mathrm{CEM}$ cells after doxorubicin treatment (Figure 5). This suggests that ROS from mitochondria may be involved in doxorubicin-induced apoptosis.

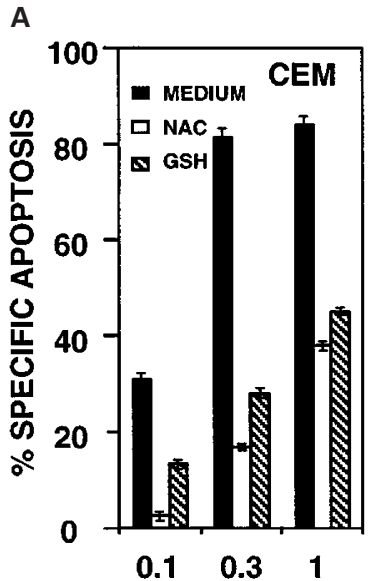

DOXORUBICIN $[\mu \mathrm{g} / \mathrm{ml}]$

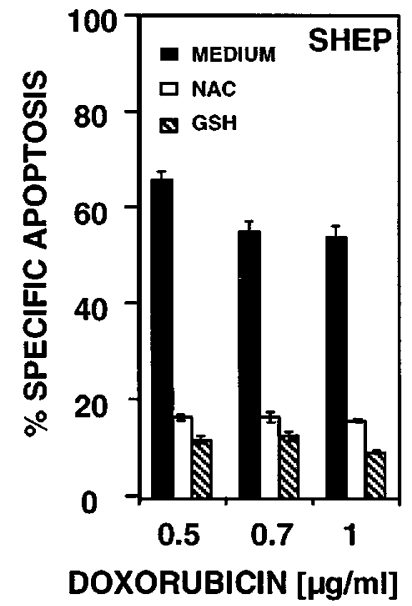

B

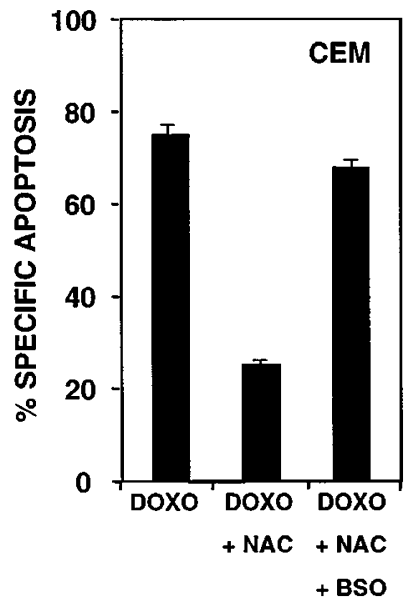

C

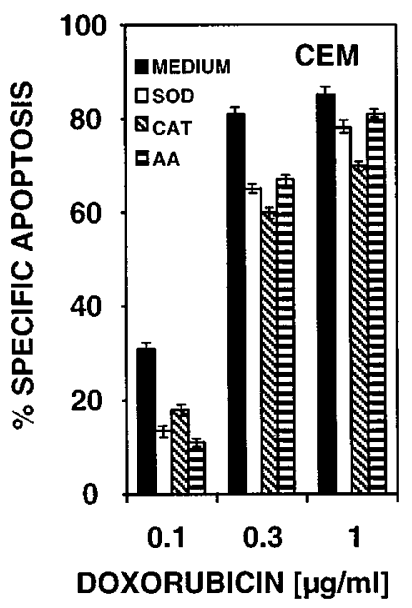

D

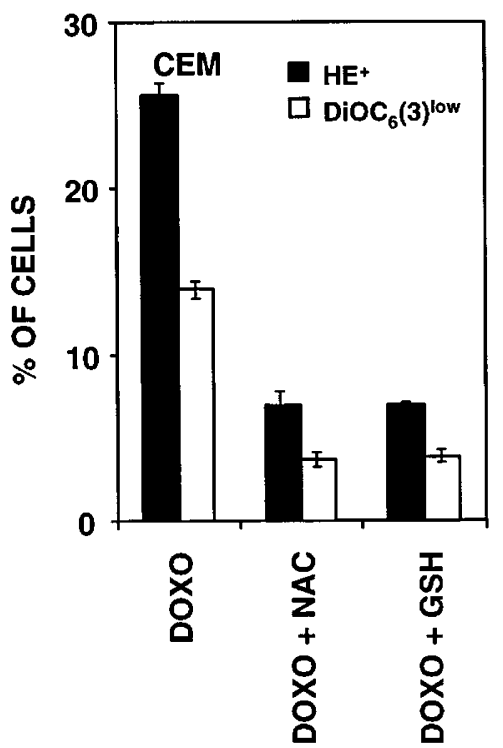

Figure 1 Effects of antioxidants in doxorubicin-induced apoptosis. (A) Effects of NAC and GSH in doxorubicin-induced apoptosis in chemosensitive leukemia cells (CEM) and neuroblastoma cells (SHEP). CEM and SHEP cells were preincubated with MEDIUM (black bars), NAC (white bars) (1.5 mg/ml for CEM and $1.8 \mathrm{mg} / \mathrm{ml}$ for SHEP) or GSH (hachted bars) $(1 \mathrm{mg} / \mathrm{ml})$ in 96 well plates $\left(2 \times 10^{4}\right.$ cells/well) for $2 \mathrm{~h}$ at $37^{\circ} \mathrm{C}$ by addition of doxorubicin in concentrations as indicated. After $30 \mathrm{~h}$ for CEM and after $72 \mathrm{~h}$ for SHEP cells percentage of apoptotic cells were determined by FSC/SSC in leukemia cells, ${ }^{68}$ and by hypodiploid DNA in neuroblastoma cells as described ${ }^{67}$ Data are given as mean of triplicates with a standard deviation (SD) of less than $10 \%$. Similar results were obtained in three independent experiments. Percentage of specific cell death was calculated as follows: $100 \times$ (experimental dead cells (\%) - spontaneous dead cells in medium $(\%) / 100 \%$ - spontaneous dead cells in medium (\%)). (B) Reduction of the inhibitory effect of NAC by BSO. CEM cells were preincubated with NAC (1.5 mg/ml) or NAC and BSO $(1.5 \mathrm{mg} / \mathrm{ml} \mathrm{NAC}$ and $30 \mu \mathrm{g} / \mathrm{ml} \mathrm{BSO})$ in 96 well plates $\left(2 \times 10^{4}\right.$ cells/well) for $2 \mathrm{~h}$ at $37^{\circ} \mathrm{C}$ by addition of $0.3 \mu \mathrm{g} / \mathrm{ml}$ doxorubicin. After $30 \mathrm{~h} \mathrm{percentage} \mathrm{of}$ apoptotic cells were determined by FSC/SSC as described. Data are given as mean of triplicates with a SD of less than $10 \%$. Similar results were obtained in three independent experiments. Percentage of specific cell death was calculated as described in A. (C) Effects of catalase, superoxide dismutase and ascorbic acid in doxorubicin-induced apoptosis in chemosensitive leukemia cells (CEM). CEM cells were preincubated with MEDIUM, $100 \mu \mathrm{g} / \mathrm{ml}$ superoxide dismutase (SOD), $100 \mu \mathrm{g} / \mathrm{ml}$ catalase (CAT), and $0.1 \mu \mathrm{g} / \mathrm{ml}$ ascorbic acid (AA) in 96 well plates $\left(2 \times 10^{4}\right.$ cells/well) for $2 \mathrm{~h}$ at $37^{\circ} \mathrm{C}$ by addition of doxorubicin at concentrations indicated. After $30 \mathrm{~h}$ percentage of apoptotic cells were determined by FSC/SSC. Data are given as mean of triplicates with a SD of less than $10 \%$. Similar results were obtained in three independent experiments. Percentage of specific cell death was calculated as described in $\mathbf{A}$. (D) Effects of NAC or GSH in doxorubicininduced apoptosis on ROS generation and $\Delta \Psi_{\mathrm{m}}$ in chemosensitive leukemia cells (CEM). CEM cells were incubated with $0.3 \mu \mathrm{g} / \mathrm{ml}$ doxorubicin (DOXO), pretreated with $1.5 \mathrm{mg} / \mathrm{ml} \mathrm{NAC} \mathrm{(DOXO+NAC)} \mathrm{or} 1 \mathrm{mg} / \mathrm{ml} \mathrm{GSH}(\mathrm{DOXO}+\mathrm{GSH})$ for $2 \mathrm{~h}$ by addition of $0.3 \mu \mathrm{g} / \mathrm{ml}$ doxorubicin at $37^{\circ} \mathrm{C}$. After $12 \mathrm{~h}$ frequence of cells with enhanced $\mathrm{ROS}\left[\mathrm{HE}^{+}\right]$(black bars) and reduced $\Delta \Psi_{\mathrm{m}}\left[\mathrm{DiOC}_{6}(3)^{\text {low }}\right]$ (white bars) were measured as described. ${ }^{34,38}$ Data are given as mean of triplicates with a SD of less than $10 \%$. Similar results were obtained in three independent experiments 


\section{Reversal of doxorubicin-resistance and deficient activation of the CD95 system by downregulation of GSH}

We next asked whether downregulation of intracellular GSH in resistant cell lines would reverse drug-resistance. Doxorubicin-resistant CEM (CEM $\left.{ }^{\mathrm{DOXOR}}\right)$ and doxorubicin-resistant SHEP (SHEP DOXOR) cells were incubated for $24 \mathrm{~h}$ in the presence or absence of cycloheximide $(\mathrm{CHX})$ which has been found to reduce intracellular GSH concentrations at non-toxic concentrations ${ }^{42}$ in addition to inhibition of protein synthesis or L-buthionine-(S,R)-sulfoximine (BSO) which has been found to inhibit GSH synthesis. ${ }^{42,47}$ In cytofluorometric analysis using $\mathrm{mBCl}$ to detect $\mathrm{GSH},{ }^{44}$ downregulation of GSH concentrations was found in CEM DOXOR and SHEP ${ }^{\text {DOXOR }}$ cells after treatment with highest non-toxic concentration of $\mathrm{CHX}$ or BSO (Figure $6 \mathrm{~A}$ ).
To see whether a downregulation of GSH concentrations could reverse doxorubicin-resistance, CEM ${ }^{\mathrm{DOXOR}}$ and SHEP DOXOR cells were incubated in the presence or absence of the highest non-toxic dose of $\mathrm{CHX}$ in addition to doxorubicin. After $24 \mathrm{~h}$ for $\mathrm{CEM}^{\mathrm{DOXOR}}$ cells and after $72 \mathrm{~h}$ for SHEP ${ }^{\text {DOXOR }}$ cells sensitivity to doxorubicin-induced apoptosis was measured by FSC/SSC analysis (Figure 6B). These time points were chosen according to the different kinetic of drug-induced apoptosis in both cell lines. In doxorubicin-resistant cells, induction of apoptosis was only found in the presence of $\mathrm{CHX}$. Similar results were observed in $\mathrm{CEM}^{\mathrm{DOXOR}}$ cells pretreated with $\mathrm{BSO}$ for $12 \mathrm{~h}$ before doxorubicin treatment (Figure 6B). Furthermore, addition of high non-toxic doses of GSH reversed the effect of BSO or $\mathrm{CHX}$ (data not shown). These data suggest that downregulation of intracellular GSH using $\mathrm{CHX}$ or BSO might reverse doxorubicin-resistance.
A

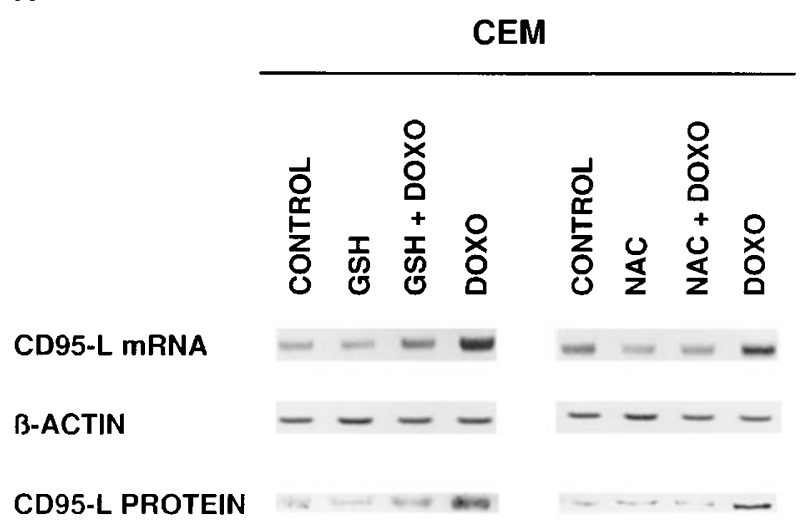

B

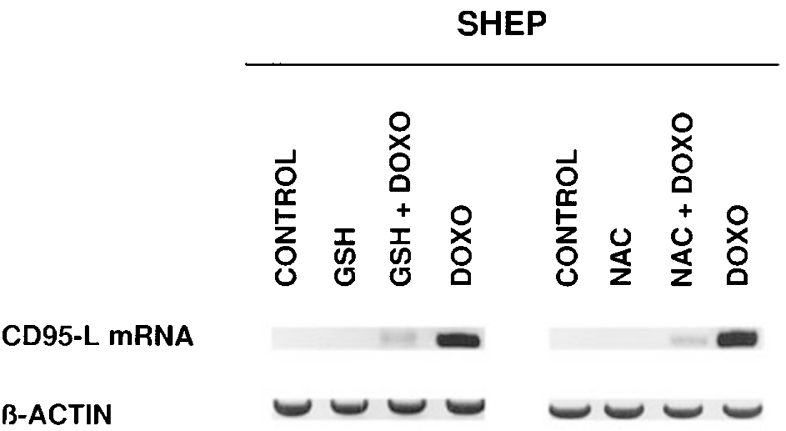

C
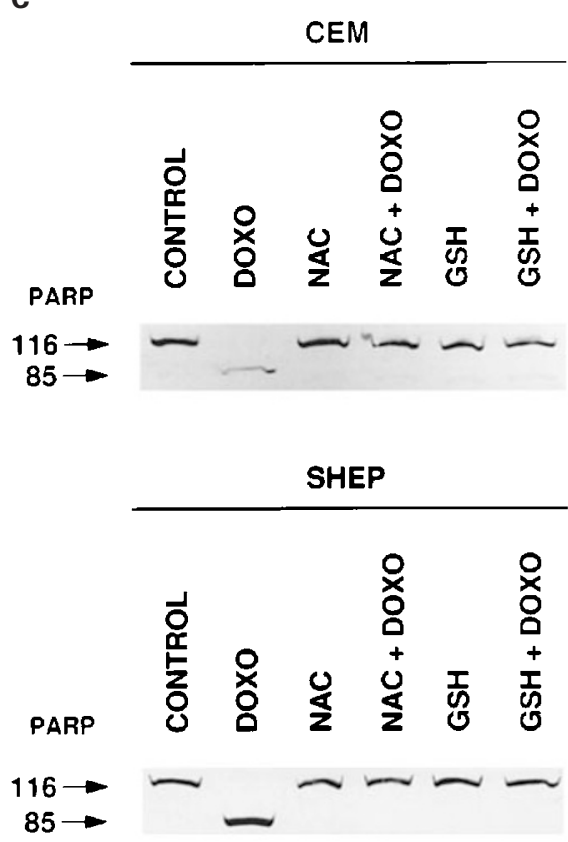

Figure 2 Inhibition of doxorubicin-induced CD95-L expression and PARP cleavage in chemosensitive leukemia cells (CEM) and neuoblastoma cells (SHEP) by NAC and GSH. (A) Inhibition of CD95-L mRNA and CD95-L protein expression in chemosensitive leukemia cells (CEM) by GSH and NAC. CEM cells were incubated with medium (CONTROL), incubated with $1 \mathrm{mg} / \mathrm{ml} \mathrm{GSH}(\mathrm{GSH})$ or $1.5 \mathrm{mg} / \mathrm{ml} \mathrm{NAC} \mathrm{(NAC),} \mathrm{preincubated} \mathrm{with} 1 \mathrm{mg} / \mathrm{ml} \mathrm{GSH}$ or $1.5 \mathrm{mg} / \mathrm{ml} \mathrm{NAC} \mathrm{for} 2 \mathrm{~h}$ at $37^{\circ} \mathrm{C}$ before addition of $0.3 \mu \mathrm{g} / \mathrm{ml}$ doxorubicin (GSH+DOXO, NAC+DOXO) or incubated with $0.3 \mu \mathrm{g} / \mathrm{ml}$ doxorubicin (DOXO) at $37^{\circ} \mathrm{C}$. After $2 \mathrm{~h} \mathrm{CD95-L} \mathrm{mRNA} \mathrm{expression}$ was determined by RT-PCR. Human $\beta$-actin served as control for equal loading and RNA integrity. After $8 \mathrm{~h}$ CD95-L protein was detected by Western blot. Protein loading was controlled by Ponceau Red staining. (B) Inhibition of CD95-L mRNA and CD95-L protein expression in chemosensitive neuroblatoma cells (SHEP) by NAC and GSH. SHEP cells were incubated with medium (CONTROL), incubated with $1 \mathrm{mg} / \mathrm{ml} \mathrm{GSH}$ (GSH) or $1.8 \mathrm{mg} / \mathrm{ml} \mathrm{NAC} \mathrm{(NAC),} \mathrm{preincubated} \mathrm{with} 1 \mathrm{mg} / \mathrm{ml}$ GSH or $1.8 \mathrm{mg} / \mathrm{ml} \mathrm{NAC}$ for $2 \mathrm{~h}$ at $37^{\circ} \mathrm{C}$ before addition of $0.5 \mu \mathrm{g} / \mathrm{ml}$ doxorubicin (GSH+DOXO, NAC+DOXO), or incubated with $0.5 \mu \mathrm{g} / \mathrm{ml}$ doxorubicin $(\mathrm{DOXO})$ at $37^{\circ} \mathrm{C}$. After $24 \mathrm{~h}$ CD95-L mRNA expression was determined by RT-PCR. Human $\beta$-actin served as control for equal loading and RNA integrity. (C) Inhibiton of doxorubicin-induced cleavage of the prototype caspase substrate PARP (poly(ADP-ribose)polymerase) in chemosensitive leukemia cells (CEM) and neuroblastoma cells (SHEP) by NAC and GSH. CEM cells were incubated with medium (CONTROL), incubated with $0.3 \mu \mathrm{g} / \mathrm{ml}$ doxorubicin (DOXO), incubated with $1.5 \mathrm{mg} / \mathrm{ml} \mathrm{NAC} \mathrm{(NAC)} \mathrm{or} 1 \mathrm{mg} / \mathrm{ml} \mathrm{GSH}$ (GSH), or preincubated with $1.5 \mathrm{mg} / \mathrm{ml} \mathrm{NAC}$ or $1 \mathrm{mg} / \mathrm{ml} \mathrm{GSH}$ for $2 \mathrm{~h}$ at $37^{\circ} \mathrm{C}$ before addition of $0.3 \mu \mathrm{g} / \mathrm{ml}$ doxorubicin (NAC+DOXO, GSH+DOXO) for $30 \mathrm{~h}$. SHEP cells were incubated with medium (CONTROL), incubated with $0.5 \mu \mathrm{g} / \mathrm{ml}$ doxorubicin (DOXO), incubated with $1.8 \mathrm{mg} / \mathrm{ml}$ NAC (NAC) or $1 \mathrm{mg} / \mathrm{ml} \mathrm{GSH}(\mathrm{GSH})$, or preincubated with $1.8 \mathrm{mg} / \mathrm{ml} \mathrm{NAC}$ or $1 \mathrm{mg} / \mathrm{ml} \mathrm{GSH}$ for $2 \mathrm{~h}$ at $37^{\circ} \mathrm{C}$ before addition of $0.5 \mu \mathrm{g} / \mathrm{ml}$ doxorubicin $(\mathrm{NAC}+\mathrm{DOXO}$, $\mathrm{GSH}+\mathrm{DOXO}$ ) for $72 \mathrm{~h}$. PARP protein was detected by Western blot. Protein loading was controlled by Ponceau Red staining 
In addition to increased GSH levels and deficient reduction of $\Delta \Psi_{\mathrm{m}}$ and ROS generation, CEM ${ }^{\mathrm{DOXOR}}$ and SHEP ${ }^{\mathrm{DOXOR}}$ failed to upregulate CD95-L expression after doxorubicin-treatment (Figure 7). ${ }^{19}$ Since downregulation of intracellular GSH levels and hyperproduction of ROS restored doxorubicin sensitivity in doxorubicin-resistant cells we asked whether downregulation of GSH with hyperproduction of ROS would also restore upregulation of CD95-L following drug treatment. After incubation of doxorubicin-resistant cell lines $\left(\mathrm{CEM}^{\mathrm{DOXOR}}, \mathrm{SHEP}^{\mathrm{DOXOR}}\right.$ ) with doxorubicin alone or in the presence of highest nontoxic dose of $\mathrm{CHX}$ or BSO, CD95-L mRNA expression was analyzed by RT-PCR. Upregulation of CD95-L mRNA was only observed in doxorubicin-resistant cells lines pretreated with $\mathrm{CHX}$ or BSO (Figure 7). Production of CD95-L protein in doxorubicin-resistant cells treated with $\mathrm{CHX}$ was also confirmed by Western blot (data not shown). Activation of caspases downstream of CD95-triggering system by doxorubicin after treatment with the highest non-toxic dose of $\mathrm{CHX}$ was also indicated by PARP cleavage (data not shown). Taken together, these results demonstrate that induction of CD95-L and subsequent activation of downstream apoptosis effector pathways by doxorubicin is controlled by intracellular GSH levels and ROS which may be produced in mitochondria. Downregulation of high GSH levels in drug-resistant cells and hyperproduction of ROS may reverse the defect in drug-induced activation of CD95.

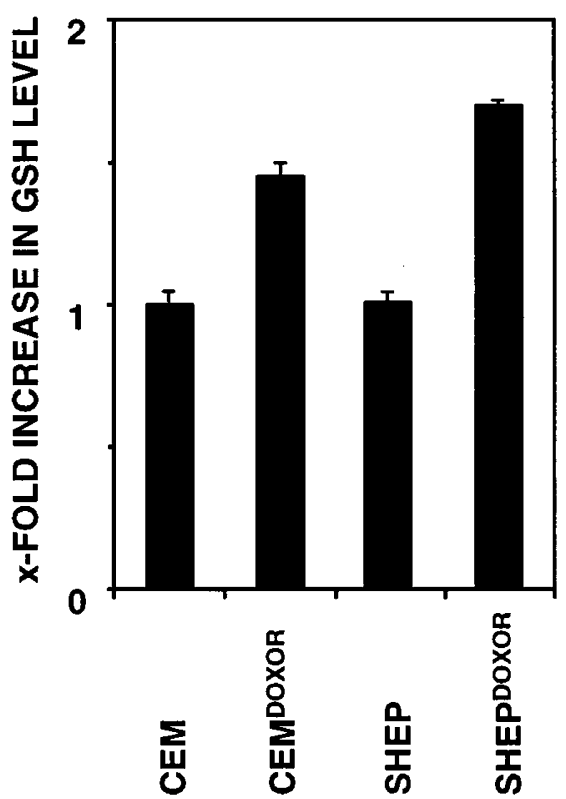

Figure 3 Analysis of intracellular GSH content of chemosensitive parental and doxorubicin-resistant (DOXOR) leukemia cells (CEM) and neuroblastoma cells (SHEP). For determination of intracellular GSH chemosensitive parental and doxorubicin-resistant (DOXOR) leukemia cells (CEM) and neuroblastoma cells (SHEP) were labeled with $\mathrm{mBCl}$ and analyzed by cytofluorometry. Data of doxorubicin-resistant cells are shown as $x$-fold increase in GSH levels comparison to chemosensitive parental cell lines. Data are given as mean of triplicates with a SD of less than $10 \%$. Similar results were obtained in three independent experiments

\section{Discussion}

Sensitivity and resistance of tumor cells for cytotoxic drugs seems to depend on activation of apoptosis pathways which may involve death receptor pathways such as the CD95 system. Treatment with cytotoxic drugs induces CD95 and CD95-L expression and may trigger autocrine or paracrine death. ${ }^{18-25}$ Deficiences in this system may lead to resistance

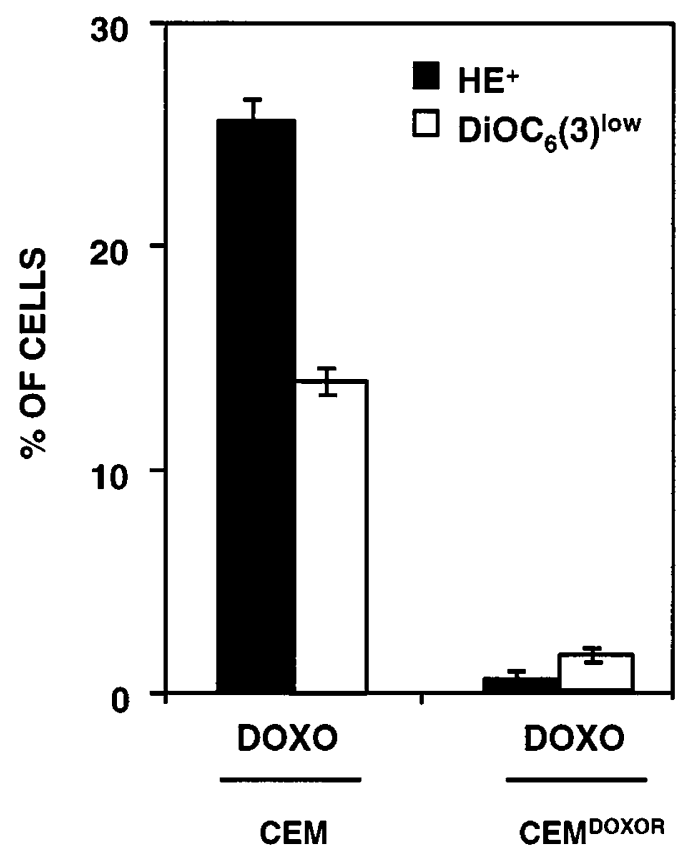

Figure 4 Effects of doxorubicin-induced apoptosis on ROS generation and $\Delta \Psi_{\mathrm{m}}$ in chemosensitive and doxorubicin-resistant (DOXOR) leukemia cells (CEM). Chemosensitive and doxorubicin-resistant (DOXOR) leukemia cells (CEM) were incubated with $0.3 \mu \mathrm{g} / \mathrm{ml}$ doxorubicin at $37^{\circ} \mathrm{C}$. After $12 \mathrm{~h}$ frequence of cells with enhanced ROS $\left[\mathrm{HE}^{+}\right]$(black bars) and reduced $\Delta \Psi_{\mathrm{m}}\left[\mathrm{DiOC}_{6}\right.$ $(3)^{\text {low }}$ (white bars) were measured as described. ${ }^{34,36,38}$ Data are given as mean of triplicates with a SD of less than $10 \%$. Similar results were obtained in three independent experiments

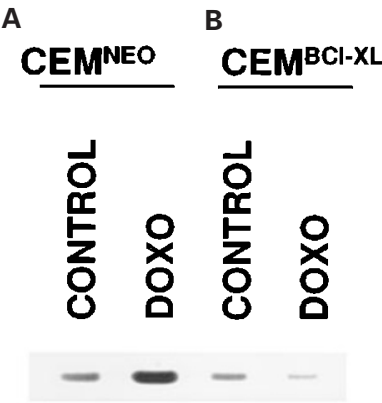

\section{B-ACTIN}

Figure 5 Inhibition of doxorubicin-induced CD95-L expression in Bcl- $\mathrm{X}_{\mathrm{L}}$ transfected cells. (A) $C E M^{N E O}$ and (B) $C E M^{B c l-X L}$ were incubated with $0.3 \mu \mathrm{g} /$ $\mathrm{ml}$ doxorubicin (DOXO) at $37^{\circ} \mathrm{C}$. After $6 \mathrm{~h}$ CD95-L mRNA expression was determined by RT-PCR. Human $\beta$-actin served as control for equal loading and RNA integrity 
towards chemotherapy independent of multi-drug resistant protein (MRP), p-glycoprotein (P-gp, MDR-1) or p53 function. ${ }^{19}$ Since cytotoxic drugs such as doxorubicin have been shown to generate ROS and may perturb mitochondrial function, ${ }^{34,35}$ alterations of the redox state may provide increased levels of CD95-L and activate the CD95/CD95-L

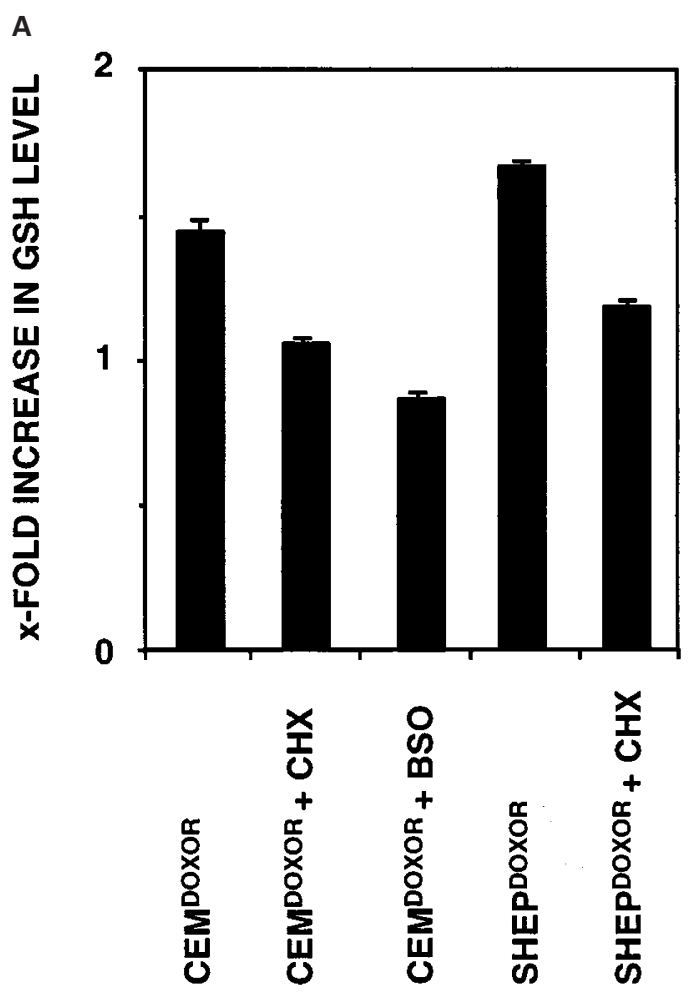

B
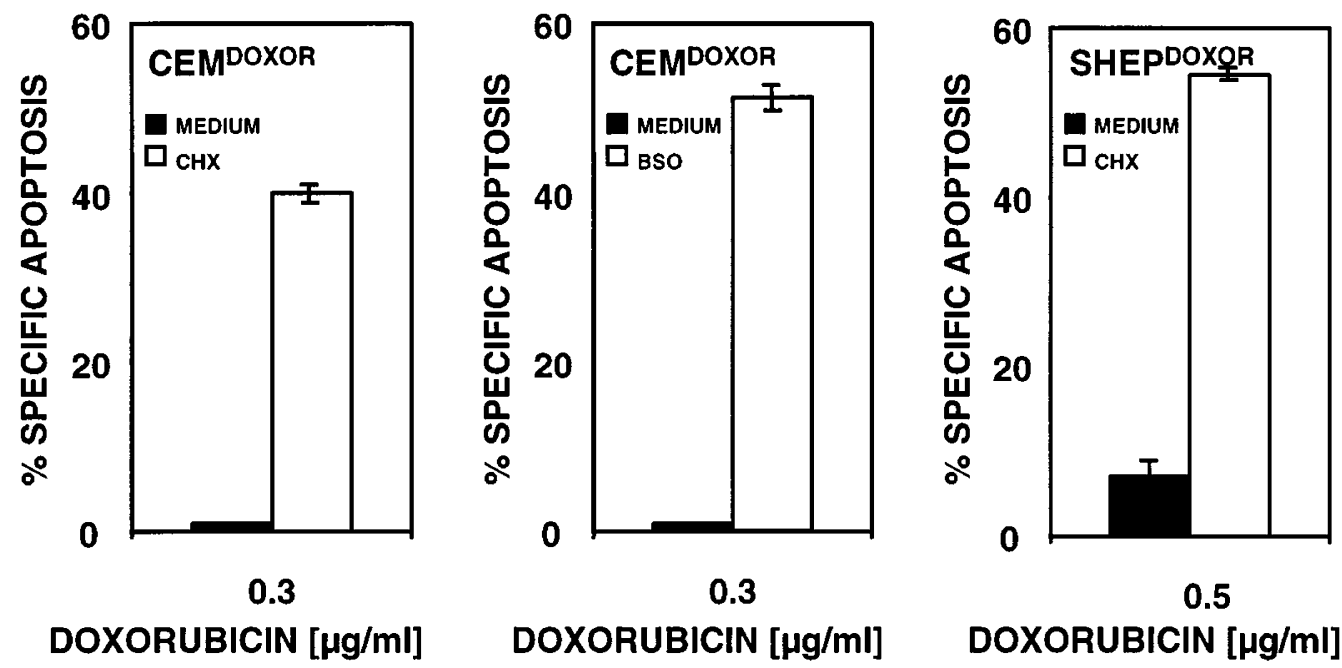

Figure 6 (A) The effect of $\mathrm{CHX}$ on intracellular GSH concentration in doxorubicin-resistant (DOXOR) leukemia cells (CEM) and neuroblastoma cells (SHEP). Doxorubicin-resistant (DOXOR) leukemia cells (CEM) and neuroblastoma cells (SHEP) were incubated in the presence or absence of $\mathrm{CHX}(1 \mu \mathrm{g} / \mathrm{ml} \mathrm{CHX}$ for $\mathrm{CEM}^{\mathrm{DOXOR}}$ or $5 \mu \mathrm{g} / \mathrm{ml} \mathrm{CHX}$ for SHEPDOXOR) or BSO $(100 \mu \mathrm{g} / \mathrm{ml})$ for $24 \mathrm{~h}$. Intracellular $\mathrm{GSH}$ concentrations were determined with $\mathrm{mBCl}$ and analyzed by cytofluorometry. Data of resistant cells and cells treated with $\mathrm{CHX}$ or BSO are shown as $\times$-fold increase in GSH levels comparison to chemosensitive parental cell lines CEM or SHEP. Data are given as mean of triplicates with a SD of less than $10 \%$. Similar results were obtained in three independent experiments. (B) The effect of $\mathrm{CHX}$ or BSO in doxorubicin-induced apoptosis in doxorubicin-resistant (DOXOR) leukemia cells (CEM) and neuroblastoma cells (SHEP). Doxorubicinresistant (DOXOR) leukemia cells (CEM) and neuroblastoma cells (SHEP) were incubated in 96 well plates $\left(2 \times 10^{4}\right.$ cells/well) with MEDIUM (black bars), CHX $\left(1 \mu \mathrm{g} / \mathrm{ml} \mathrm{CHX}\right.$ for CEM ${ }^{\mathrm{DOXOR}}$ or $5 \mu \mathrm{g} / \mathrm{ml} \mathrm{CHX}$ for SHEPDOXOR) (white bars) or preincubated for $8 \mathrm{~h}$ with $100 \mu \mathrm{g} / \mathrm{ml}$ BSO (white bars) by addition of doxorubicin at $37^{\circ} \mathrm{C}$ at concentrations indicated. After $24 \mathrm{~h}$ for CEM ${ }^{\text {DOXOR }}$ and after $72 \mathrm{~h}$ for SHEPDOXOR the percentage of apoptotic cells was measured by FSC/SSC in leukemia cells ${ }^{67}$ and by hypodiploid DNA in neuroblastoma cells as described. ${ }^{68}$ Data are given as mean of triplicates with a SD of less than $10 \%$. Similar results were obtained in three independent experiments. Percentage of specific cell death was calculated as described in Figure $1 \mathrm{~A}$ 
CEMDOXOR

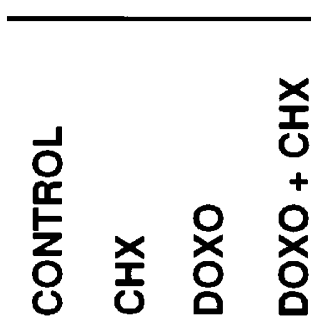

SHEPDOXOR

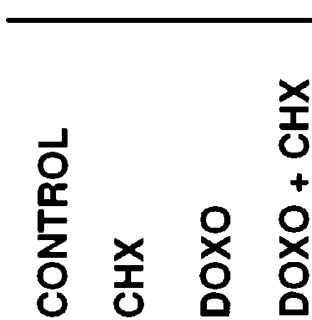

\section{CEMDOXoR}

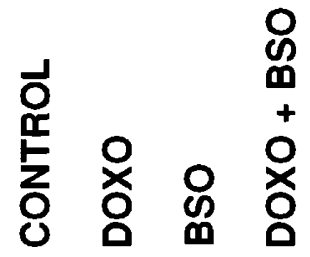

\section{CD95-L mRNA}
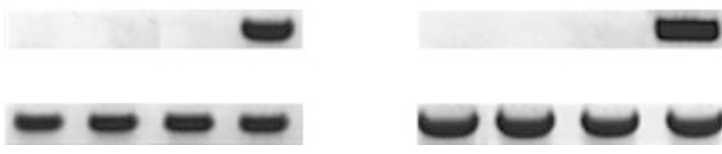

B-ACTIN

Figure 7 Induction of CD95-L expression in doxorubicin-resistant (DOXOR) leukemia cells (CEM) and neuoblastoma cells (SHEP) by CHX or BSO. Induction of CD95-L mRNA in doxorubicin-resistant (DOXOR) leukemia cells (CEM) and neuroblastoma cells (SHEP). CEM ${ }^{\text {DOXOR }}$ cells were incubated with medium (CONTROL), $1 \mu \mathrm{g} / \mathrm{ml} \mathrm{CHX} \mathrm{(CHX)} \mathrm{or} 100 \mu \mathrm{g} / \mathrm{ml}$ BSO (BSO), $0.3 \mu \mathrm{g} / \mathrm{ml}$ doxorubicin (DOXO) or $1 \mu \mathrm{g} / \mathrm{ml} \mathrm{CHX}$ by addition of $0.3 \mu \mathrm{g} / \mathrm{ml}$ doxorubicin (DOXO+CHX) at $37^{\circ} \mathrm{C}$. After $4 \mathrm{~h}$ CD95-L mRNA expression was determined by RT-PCR. Human $\beta$-actin served as control for equal loading and RNA integritiy. SHEPDOxOR cells were incubated with medium (CONTROL), $5 \mu \mathrm{g} / \mathrm{ml} \mathrm{CHX} \mathrm{(CHX),} 0.5 \mu \mathrm{g} / \mathrm{ml}$ doxorubicin (DOXO) or $5 \mu \mathrm{g} / \mathrm{ml} \mathrm{CHX}$ by addition of $0.5 \mu \mathrm{g} / \mathrm{ml}$ doxorubicin (DOXO+CHX). After $24 \mathrm{~h}$ CD95-L mRNA expression was determined by RT-PCR. Human $\beta$-actin served as control for equal loading and RNA integritiy. CEM ${ }^{\text {DoxOR }}$ cells were incubated with medium (CONTROL), preincubated for $8 \mathrm{~h}$ with $100 \mu \mathrm{g} / \mathrm{ml} \mathrm{BSO}$ (BSO), $0.3 \mu \mathrm{g} / \mathrm{ml}$ doxorubicin (DOXO) or preincubated for $8 \mathrm{~h}$ with $100 \mu \mathrm{g} / \mathrm{ml} \mathrm{BSO}$ by addition of $0.3 \mu \mathrm{g} / \mathrm{ml}$ doxorubicin (DOXO+BSO) at $37^{\circ} \mathrm{C}$. After $4 \mathrm{~h}$ CD95-L mRNA expression was determined by RT-PCR. Human $\beta$-actin served as control for equal loading and RNA integritiy

system following drug treatment. Here we report that activation of the CD95 system by doxorubicin is regulated by the redox state and ROS dependent on intracellular GSH. Since most of the molecular oxygen is consumed in the electron transport chain, mitochondria presumably are the major source of ROS. NAC, which increases intracellular GSH concentrations ${ }^{42}$ (data not shown) or GSH per se significantly reduced doxorubicin-induced apoptosis in chemosensitive CEM leukemia cells and SHEP neuroblastoma cells. However, protection from drug-induced cell death was less pronounced upon prolonged incubation (>96 h) (data not shown). In addition, preincubation with NAC or GSH before doxorubicin treatment significantly reduced loss of $\Delta \Psi_{\mathrm{m}}$ and hyperproduction of ROS and inhibited doxorubicininduced upregulation of CD95-L expression and cleavage of PARP. In contrast, non-thiol antioxidants such as catalase, which metabolizes hydrogen peroxide in cytoplasma or superoxide dismutase, which metabolizes superoxide radicals in mitochondria and cytoplasma or ascorbic acid exhibited only a moderate protection against doxorubicininduced apoptosis and did not confer a significant protection against ROS hyperproduction and upregulation of CD95-L (Figure 1C) (data not shown). Furthermore, CD95-L expression and cleavage of PARP were completely blocked in doxorubicin-resistant cells which exhibit higher GSH levels compared to chemosensitive cells. In doxorubicin-resistant cells no significant disruption of $\Delta \Psi_{\mathrm{m}}$ and hyperproduction of ROS were found in response to doxorubicin treatment. Downregulation of GSH levels by the highest non-toxic dose of $\mathrm{CHX}$ or BSO, a specific inhibitor for GSH synthesis, ${ }^{47}$ restored deficient doxorubicin-induced apoptosis and deficient upregulation of CD95-L by cytotoxic drugs in doxorubicin-resistant cells. This effect of BSO and $\mathrm{CHX}$ could be overcome by addition of high doses of GSH (data not shown). In addition, in Bcl- $\mathrm{X}_{\mathrm{L}}$ transfected CEM cells, doxorubicin- induced hyperproduction of ROS and loss of $\Delta \Psi_{m}$ was significantly reduced and activation of doxorubicin-mediated CD95-L ligand upregulation was blocked.

ROS are physiological metabolites, which may be generated from mitochondria. ${ }^{50}$ When ROS are produced in excessive amounts in mitochondria, nucleic acids, proteins, and lipids are extensively modified by oxidation. ${ }^{50}$ To counteract the harmful consequence of ROS generation mitochondria are equipped with MnSOD and a redox cycle using reduced $\mathrm{GSH}$ and $\mathrm{GSH}$ peroxidase. ${ }^{50}$ GSH is the most abundant intracellular thiol that functions in reduction of disulfide linkages of proteins and acts as an antioxidant. ${ }^{41-46}$ Hydrogen peroxide generated within the electron transport chain can undergo several fates: conversion to hydroxyl radicals with the participation of transition metals in the Haber-Weiss and Fenton reaction, reduction to water catalyzed by GSH peroxidase, with the required participation of reduced $\mathrm{GSH}$, or diffusion out of mitochondria, where it may be metabolized by the action of catalase. Since mitochondria do not contain catalase, GSH in the mitochondrial matrix is the only defense available to cope with the potential toxic effect of hydrogen peroxide produced endogeneously in the electron transport chain. ${ }^{51}$ ROS produced in a controlled fashion are involved in several biological processes. ${ }^{52}$ ROS may act as signal transducers and represent a cellular control mechanism for gene regulation. Thus, the redox environment within the cell may play a regulatory role in controlling activation and DNA binding of several transcription factors such as NF- $\kappa \mathrm{B}$, which requires mitochondrial electron transport. ${ }^{52-54}$ Generation of ROS has been suggested as a main mechanism of anthracycline cytotoxicity. Mitochondria rapidly metabolize anthracyclines to anthracycline semiquinone radicals and oxygen radicals. ${ }^{5-58}$ Anthracyclines such as doxorubicin have been found to activate $\mathrm{NF}-\kappa \mathrm{B}$ 
possibly through generation of oxygen radicals. ${ }^{53,59}$ Recently, the promotor of CD95-L, ${ }^{60}$ whose expression is induced following doxorubicin treatment, has been found to contain an NF- $\kappa \mathrm{B}$ binding site. ${ }^{25}$ Furthermore, it was found, that CD95-L mRNA induction involves ROS in hepatoma cells treated with bleomycin. ${ }^{48}$

GSH has also been found to modulate T-cell apoptosis e.g. during HIV infection. ${ }^{61}$ Seropositive individuals display GSH deficiencies in the plasma and peripheral blood lymphocytes and enhanced susceptibility to apoptotic stimuli early during the course of infection. NAC, which acts both as the precursor of glutathione and as an antioxidant by itself inhibits apoptosis in T-cells from patients. $^{62}$ T-cells from HIV-infected individuals also exhibit a significant disruption of $\Delta \Psi_{\mathrm{m}}$ compared to normal $\mathrm{T}$ cells, ${ }^{63,64}$ (also Friesen and Debatin, unpublished results). Since activation of the CD95 system, with increased levels of CD95-L has been implicated in accelerated T-cell apoptosis during HIV infection this may suggest that increased CD95-L expression is mediated by the altered redox state of $\mathrm{T}$-cells in these patients. NAC, which upregulates intracellular GSH levels may prevent depletion of HIV-infected lymphocytes. ${ }^{62}$ In contrast to HIV increased intracellular GSH levels, which prevent mitochondrial dysfunction, may prevent drug-resistant cells from druginduced apoptosis and upregulation of CD95-L by cytotoxic drugs.

Bcl-2 located in the outer mitochondrial membrane has been shown to act in an antioxidant pathway and inhibit apoptosis by suppressing the ROS function in mitochondria and antagonizing mitochondrial dysfunction. ${ }^{34,65}$ We found that in $\mathrm{BCl}-\mathrm{X}_{\mathrm{L}}$ transfected $\mathrm{CEM}$ cells doxorubicin-induced apoptosis, hyperproduction of ROS and loss of $\Delta \Psi_{\mathrm{m}}$ are significantly reduced in comparison to the parental cell line and activation of doxorubicin-induced CD95-L ligand expression is inhibited. This may suggest that $\mathrm{BCl}-\mathrm{X}_{\mathrm{L}}$ blocks doxorubicin-induced CD95-L expression by decreasing the release of ROS from mitochondria.

Taken together, our data suggest that induction of CD95$L$ expression in response to treatment with cytotoxic drugs depends on hyperexpression of ROS, which may be produced in mitochondria and which may be modulated by intracellular GSH. Thus, mitochondrial dysfunction, may not only be involved in the execution phase of apoptosis, it may also act as an initial amplifier system that contributes to drug-mediated death. Alteration of the cellular redox state e.g. by downregulation of $\mathrm{GSH}$, provides a possible mean to restore deficient activation of the CD95 system by cytotoxic drugs.

\section{Materials and Methods}

\section{Cell lines and culture conditions}

Leukemia cells (CEM) and neuroblastoma cells (SHEP) were grown in RPMI 1640 (GIBCO BRL Eggenstein, Germany) containing 10\% fetal calf serum (Conco, Wiesbaden, Germany), $10 \mathrm{mM}$ HEPES, pH 7.3 (Biochrom, Berlin, Germany), $100 \mathrm{U} / \mathrm{ml}$ penicillin (GIBCO), $100 \mu \mathrm{g} / \mathrm{ml}$ streptomycin (GIBCO) and $2 \mathrm{mM}$ L-glutamine (Biochrom). CEM ${ }^{\text {DOXOR }}$, a variant of CEM resistant towards doxorubicin up to
$1 \mu \mathrm{g} / \mathrm{ml}$ was generated by continuous culture in doxorubicin for more than 24 months. ${ }^{19}$ For experiments CEM ${ }^{\text {DOXOR }}$ cells were washed and cultured for 2 weeks in the absence of doxorubicin. Likewise SHEPDOXOR cells were generated by the same conditions as described above. $\mathrm{CEM}^{\mathrm{NEO}}$ and $\mathrm{CEM}^{\mathrm{Bcl}-\mathrm{XL}}$ were generated as described. ${ }^{66}$ All cell lines were mycoplasma free.

\section{Drugs and reagents}

Doxorubicin (Farmitalia, Milano, Italy) was freshly dissolved in sterile distilled water prior to each experiment to ensure constant quality of the preparations.

Reduced glutathione (GSH), N-acetyl-cysteine (NAC), L-buthionine-(S,R)-sulfoximine (BSO), catalase (CAT), superoxide dismutase (SOD), ascobic acid (AA) (Sigma, Deisenhofen, Germany) and cycloheximide (CHX) (Aldrich, Steinheim, Germany) was freshly dissolved in sterile destilled water prior to each experiment to ensure constant quality of the preparations.

\section{Induction of apoptosis}

For quantitative determination of apoptosis, cells were lysed in Nicoletti-buffer $(0.1 \%$ sodium citrate plus $0.1 \%$ Triton $X-100$ containing propidium iodide $50 \mu \mathrm{g} / \mathrm{ml}$ ) as described. ${ }^{67}$ Propidium iodide stained nuclei ${ }^{67}$ or forward scatter/side scatter (FSC/SSC) profile of cells ${ }^{68}$ were analyzed by flow cytometry (FACScan, Becton Dickinson, Heidelberg, Germany).

\section{Cytofluorometric analysis of mitochondrial transmembrane potential $\left(\Delta \Psi_{m}\right)$ and reactive oxygen species (ROS) generation}

To measure $\Delta \Psi_{\mathrm{m}}$ and ROS generation, cells $\left(5 \times 10^{5} / \mathrm{ml}\right)$ were incubated with 3,3'-dihexyloxacarbocyanine iodide $\left(\mathrm{DiOC}_{6}(3), 460 \mathrm{ng} /\right.$ $\mathrm{ml}$; FL-1) (Moleculare Probes, Inc., Eugene, OR, USA) for $\Delta \Psi_{\mathrm{m}}$ and dihydroethidine (HE, $126 \mathrm{ng} / \mathrm{ml}$, FL-3) (Moleculare Probes) for ROS generation for $12 \mathrm{~min}$ at $37^{\circ} \mathrm{C}$ in the dark followed by analysis on a flow cytometer (FACScan).

\section{Cytofluorometric analysis of non-oxidized glutathione}

Intracellular GSH (mainly non-oxidized glutathione) was measured by staining the cells with $40 \mu \mathrm{M}$ monochlorobimane $(\mathrm{mBCl})$ (Moleculare Probes) for $10 \mathrm{~min}$ at room temperature in the dark before measuring fluorescence on a FACS Vantage (Becton Dickinson) (excitation, wavelength $325 \mathrm{~nm}$; emission, wavelength $450 \mathrm{~nm}$ ).

\section{RT-PCR for CD95-L mRNA}

Total RNA was prepared using the Qiagen RNA kit (Qiagen, Hilden, Germany). RNA was converted to cDNA by reverse transcription and amplified by polymerase chain reaction (PCR) in a thermocycler (Stratagene, Heidelberg, Germany) using the Gene Amplification kit (Perkin Elmer, Branchburg, NJ, USA) following the manufacturer's instructions. Primers used for amplification of CD95-L fragment were according to the sequence of human CD95-L. ${ }^{69}$

Expression of $\beta$-actin (MWG-Biotech, Ebersberg, Germany) was used as a standard for RNA integritiy and equal gel loading. PCRreaction products were run at $60 \mathrm{~V}$ for $2 \mathrm{~h}$ on a $1.5 \%$ agarose gel stained with ethidiumbromid and visualized by UV illumination. 


\section{Western blot analysis}

Proteins were extracted from cells lysed for 30 min at $4^{\circ} \mathrm{C}$ in PBS with $0.5 \%$ Triton X (Serva, Heidelberg, Germany) and $1 \mathrm{mM} \mathrm{PMSF} \mathrm{(Sigma)}$ followed by high-speed centrifugation. Membrane proteins were eluated by buffer containing $0.1 \mathrm{M}$ glycin/ $\mathrm{HCl}, \mathrm{pH} 3.0$ in PBS and lower Tris, $\mathrm{pH}$ 8.8. Protein concentration was assayed using bicinchoninic acid (Pierce, Rockford, USA). $100 \mu \mathrm{g}$ protein per lane was separated by $12 \%$ SDS-PAGE and electroblotted to nitrocellulose (Amersham, Braunschweig, Germany). Equal protein loading was controlled by Ponceau red staining of membranes. After blocking for $1 \mathrm{~h}$ in PBS supplemented with 2\% BSA (Sigma) and $0.1 \%$ Tween 20 (Sigma), immunodetection of PARP and CD95-L was done using rabbit anti-PARP polyclonal antibody (Enzyme Systems Products, Dublin, CA, USA), rabbit anti-CD95-L polyclonal antibody IgG (Santa Cruz Biotechnology, Santa Cruz, California) and horseradish peroxidase-conjugated goat anti-rabbit IgG. Enhanced chemiluminescence system (ECL) (Amersham) was used for detection.

\section{Acknowledgements}

We thank Peter Krammer, Markus Peter and Carsten Scaffidi for providing the $\mathrm{Bcl}-\mathrm{X}_{\mathrm{L}}$ overexpressing $\mathrm{CEM}$ cells.

\section{References}

1. Barry MA, Behnke CA and Eastman A (1990) Activation of programmed cell death (apoptosis) by cisplatin, other anticancer drugs, toxins and hyperthermia. Biochem. Pharmacol. 40: 2353-2362

2. Hickman JA, Potten CS, Merrit AJ and Fisher TC (1994) Apoptosis and cancer chemotherapy. Philos. Trans. R. Soc. Lon. B. Biol. Sci. 345: 319-325

3. Debatin KM, Goldman CK, Bamford R, Waldmann TA and Krammer PH (1990) Monoclonal antibody-mediated apoptosis in adult T cell leukemia. Lancet 335: $497-500$

4. Debatin KM, Goldman CK, Waldmann TA and Krammer PH (1993) APO-1 induced apoptosis of leukemia cells from patients with adult $\mathrm{T}$ cell leukemia. Blood 81: 2972-2977

5. Krammer PH, Dhein J, Walczak H, Behrmann I, Mariani S, Matiba B, Fath M, Daniel PT, Knipping E, Westendorp MO, Stricker K, Bäumler C, Hellbardt S, Germer M, Peter ME and Debatin KM (1994) The role of APO-1-mediated apoptosis in the immune system. Immunol. Rev. 142: 175-191

6. Nagata S (1997) Apoptosis by death factor. Cell 88: 355-365

7. Trauth BC, Klas C, Peter AMJ, Matz S, Möller P, Falk W, Debatin KM and Krammer PH (1989) Monoclonal antibody-mediated tumor regression by induction of apoptosis. Science 245: 301-305

8. Debatin KM (1996) Disturbances of the CD95 (APO-1/Fas) system in disorders of lymphohaematopoietic cells. Cell Death Differ. 3: 185-189

9. Itoh N, Yonehara S, Ishii A, Yonehara M, Mizushima S, Sameshima M, Hase A, Sato $N$ and Nagata S (1991) The polypeptide encoded by the cDNA for human cell surface antigen Fas can mediate apoptosis. Cell 66: 233-243

10. Kischkel FC, Hellbardt S, Behrmann I, Gremer M, Pawlita M, Krammer PH and Peter M (1995) Cytotoxicity-dependent APO-1 (Fas/CD95)-associated proteins (CAP) form a death-inducing signalling complex (DISC) with the receptor. EMBO J. $14: 5579-5588$

11. Klas C, Debatin KM, Jonker RR and Krammer PH (1993) Activation interferes with the apoptotic pathway in mature human T cells. Internat. Immunol. 5: 625630

12. Oehm A, Behrmann I, Falk W, Pawlita M, Maier G, Klas C, Li-Weber M, Richards $\mathrm{S}$, Dhein J, Trauth B, Ponstingl $\mathrm{H}$ and Krammer PH (1992) Purification and molecular cloning of the APO-1 cell surface antigen, a member of the tumor necrosis factor/nerve growth factor receptor superfamily. J. Biol. Chem. 267: $10709-10715$

13. PeterME, Kischkel FC, Hellbrandt S, Chinnaiyan AM, KrammerPH and Dixit VM (1996) CD95 (APO-1/Fas)-associating signaling proteins. Cell Death Differ. 3: $161-170$
14. Muzio M, Chinnaiyan AM, KischkelFC, O'Rourke K, Shevchenko A, NiJ, Scaffid C, Bretz JD, Zhang M, Gentz R, Mann M, Krammer PH, Peter ME and Dixit VM (1996) FLICE, a novel FADD-homologous ICE/CED-3-like protease, is recruited to the CD95 (Fas/APO-1) death-inducing signaling complex. Cell 85: 817-827

15. Dhein J, Walczak H, Bäumler C, Debatin KM and Krammer PH (1995) Autocrine T cell suicide mediated by APO-1 (Fas/CD95). Nature 373: 438-441

16. Suda T, Takahashi S, Golstein P and Nagata S (1993) Molecular cloning and expression of the Fas ligand, a novel member of the tumor necrosis factor family. Cell 75: $1169-1178$

17. Tanaka M, Suda T, Takahashi T and Nagata, S (1995) Expression of the functional soluble form of human Fas ligand in activated lymphocytes. EMBO J. 14: $1129-1135$

18. Friesen C, Herr, I, Krammer PH and Debatin KM (1996) Involvement of the CD95 (APO-1/Fas) receptor/ligand system in drug-induced apoptosis in leukemia cells. Nature Medicine 2: $574-577$

19. Friesen C, Fulda S and Debatin KM (1997) Deficient activation of the CD95 (APO1/Fas) system in drug-resistant cells. Leukemia 11: 1833-1841

20. Friesen C, Fulda S and Debatin KM (1999) Cytotoxic drugs and the CD95 pathway. Leukemia 13: in press

21. Fulda S, Sieverts H, Friesen C, Herr l and Debatin K-M (1997) The CD95 (APO-1/ Fas) system mediates drug-induced apoptosis in neuroblastoma cells. Cancer Res. 57: 3823-3829

22. Fulda S, Los M, Friesen C and Debatin K-M (1998) Chemosensitivity of solid tumor cells in vitro is related to activation of the CD95 system. Int. J. Cancer 76: $105-114$

23. Müller M, Strand S, Hug H, Heinemann EM, Walczak H, Hofmann WJ, Stremmel W, Krammer PH and Galle PR (1997) Drug-induced apoptosis in hepatoma cells is mediated by the CD95 (APO-1/Fas) receptor/ligand system and involves activation of wilde-type p53. J. Clin. Invest. 99: 403-413

24. Houghton JA, Harwood FG and Tillman DM (1997) Thymineless death in colon carcinoma cells is mediated via Fas signaling. Proc. Natl. Acad. Sci. USA 94 $8144-8149$

25. Kasibatla S, Brunner T, Genestier L, Echeverri F, Mahboubi A and Green DR (1998) DNA damaging agents induce expression of FAS ligand and subsequent apoptosis in T lymphocytes via activation of NF- $\kappa$ B. Molecular Cell 1: $543-551$

26. Strand S, Hofmann WJ, Grambihler A, Hug H, Volkmann M, Otto G, Wesch H Mariani SM, Hack V, Stremmel W, Krammer PK and Galle PR (1998) Hepatic failure and liver damage in acute Wilson's disease involve CD95 (APO-1/fas) mediated apoptosis. Nature Medicine 4: 588-593

27. Eischen CM, Kottke TJ, Martins LM, Basi GS, Tung SJ, Earnshaw WC, Leibson PJ and Kaufmann SH (1997) Comparison of apoptosis in wild-type and Fasresistant cells: chemotherapy-induced apoptosis is not dependent on Fas/Fas ligand interaction. Blood 90: 935-943

28. Ferrari D, Stepczynska A, Los M, Wesselborg S and Schulze-Osthoff K (1998) Differential regulation and ATP requirement for caspase-8 and caspase-3 activation during CD95- and anticancer drug-induced apoptosis. J. Exp. Med. 188: $979-984$

29. Gamen S, Anel A, Lasierra P, Alava MA, Martinez-Lorenzo MJ, Pineiro A and Naval J (1997) Doxorubicin-induced apoptosis in human T cell leukemia is mediated by caspase-3 activation in a Fas-independent way. FEBS Lett. 417: $360-364$

30. Kataoka T, Schroter M, Hahne M, Schneider P, Irmler M, Thome M, Froelich CJ and Tschopp J (1998) FLIP prevents apoptosis induced by death receptors but not by perforin/granzyme $B$, chemotherapeutic drugs, and gamma irradiation. J Immunol. 161: 3936-3942

31. McGahon AJ, Pereira Costa AP, Daly L and Cotter TG (1998) Chemotherapeutic drug-induced apoptosis in human leukaemic cells is independent of Fas (APO-1) CD95) receptor/ligand system. Br. J. Haematol 101: 539-547

32. Tolomeo M, Dusonchet L, Meli M, Grimaudo S, D'Alessandro N, Papoff G, Ruberti $G$ and Rausa L (1998) The CD95/CD 95 ligand system is not the majo effector in anticancer drug-mediated apoptosis. Cell Death Differ. 5: 735-742

33. Villunger A, Egle A, Kos M, Hartmann BL, Stephan G, Kofler Rand Greil R (1997) Drug-induced apoptosis is associated with enhanced fas (Apo-1/CD95) ligand expression but occurs independently of Fas (Apo-1/CD95) signaling in human Tacute lymphatic leukemia cells. Cancer Res. 57: 3333-3334

34. Decaudin D, Geley S, Hirsch T, Castedo M, Marchetti P, Macho A, Kofler R and Kroemer $\mathrm{G}$ (1997) Bcl-2 and $\mathrm{Bcl}-\mathrm{X}_{\mathrm{L}}$ antagonize the mitochondrial dysfunction preceding nuclear apoptosis induced by chemotherapeutic agents. Cancer Res. 57: $62-67$ 
35. Kroemer G (1997) Mitochondrial implication in apoptosis towards an endosymbiont hypothesis of apoptosis evolution. Cell Death Differ. 214: 443456

36. Marchetti P, Castedo M, Susin SA, Zamzami N, Hirsch T, Macho A, Haeffner A Hirsch F, Geuskens M and Kroemer G (1996) Mitochondrial permeability transition is a central coordinating event of apoptosis. J. Exp. Med. 184: 11551160

37. Zamzami N, Marchetti P, Castedo M, Zanin C, Vayssiere JL, Petit PX and Koemer G (1995) Reduction in mitochondrial potential constitutes an early irreversible step of programmed lymphocytes death in vivo. J. Exp. Med. 181 $1661-1672$

38. Zamzami N, Susin SA, Marchetti P, Hirsch T, Gomez-Monterry I, Castedo M and Kroemer G (1996) Mitochondrial control of nuclear apoptosis. J. Exp. Med. 183 $1533-1544$

39. Doroshow JH (1986) Prevention of doxorubicin-induced killing of MCF-7 human breast cancer cells by oxygen radical scavengers and iron chelating agents. Biochem. Biophys. Res. Commun. 135: 330-335

40. Sandstrom PA, Mannie MD andButtke TM (1994) Inhibition of activation-induced death in T cells hybridomas by thiol antioxidants: oxidative stress as a mediator of apoptosis. J. Leuk. Biol. 55: 221-226

41. Cervantes A, Pinedo HM, Lankelma J and Schuurhuis GJ (1988) The role of oxygen-derived free radicals in the cytotoxicity of doxorubicin in multi-drug resistant and sensitive human ovarian cancer cells. Cancer Letters 41: 169-177

42. Chiba T, Takahashi S, Sato N, Ishii S and Kikuchi K (1996) Fas-mediated apoptosis is modulated by intracellular glutathione in human T cells. Eur. J. Immunol. 26: 1164-1169

43. Dèas O, Dumont C, Mollereau B, Mètivier D, Pasquier C, Bernard-Pomier G, Hirsch F, Charpentier B and Senik A (1997) Thiol-mediated inhibition of Fas and CD2 apoptotic signaling in activated human peripheral T cells. Int. Immunol. 9 : $117-125$

44. Hedley D and Chow S (1994) Evaluation of methods for measuring cellular glutathione content using flow cytometry. Cytometry 15: 349-358

45. Hedley D and Chow S (1994) Glutathione and Cellular Resistance to anti-Cancer Drugs. Methods Cell Biol. 42: 31-44

46. Sato N, Iwata S, Nakamura K, Hori T, Mori K and Yodoi J (1995) Thiol-mediated redox regulation of apoptosis. Possible roles of cellular thiols other than glutathione in T cells apoptosis. J. Immunol. 154: 3194-3203

47. Dusre L, Mimnaugh EG, Myers CE and Sinha BK (1989) Potentiation of doxorubicin cytotoxicity by buthionine sulfoximine in multidrug-resistant human breast tumor cells. Cancer Res. 49: 511-515

48. Hug H, Strand S, Grambihler A, Galle J, Hack V, Stremmel W, Krammer PH and Galle PR (1997) Reactive oxygen intermediates are involved in the induction of CD95 ligand mRNA expression by cytostatic drugs in hepatoma cells J. Biol. Chem. 272: $28191-28193$

49. Tewari M, Quan LT, O'Rourke K, Desnoyers S, Zeng Z, Beidler DR, Poirier GG, Salvesen GS and Dixit VM (1995) Yama/CPP32 $\beta$, a mammalian homolog of Ced-3, is a CrmA-inhibitable protease that cleaves the death substrate poly(ADP-ribose) polymerase. Cell 81: 801-809

50. Richter C, Gogvadze V, Laffranchi R, Schlapbach R, Schweizer M, Suter M, Walter $P$ and Yaffee M (1995) Oxidants in mitochondria: from physiologica diseases. Biochim. Biophys. Acta 1271: $67-74$

51. Chance B, Sies $H$ and Boveris A (1979) Hydrogen peroxide metabolism in mammalian organs. Physiol. Rev. 59: 527-605

52. Abate C, Patel L, Rauscher III FJ and Curran T (1990) Redox regulation of Fos and Jun DNA binding activity in vitro. Science 249: 1157-1161
53. Gracia-Ruiz C, Colell A, Morales A, Kaplowitz N and Fernandez-Checa JC (1995) Role of oxidative stress generated from the mitochondrial electron transport chain and mitochondrial glutathione status in loss of mitochondrial function and activation of transcription factor NF- $\kappa \mathrm{B}$ : studies with isolated mitochondria and rat hepatocytes. Mol. Pharmacol. 48: 825-834

54. Schulze-Osthoff K, Bakker AC, Vanhaesebroeck B, Beyaert R, Jacob WA and Fiers W (1992) Cytotoxic activity of tumor necrosis factor is mediated by early damage to mitochondrial functions. J. Biol. Chem. 267: 5317-5323

55. Doroshow JH (1983) Anthracycline antibiotic-stimulated superoxide, hydrogen peroxide and hydroxyl radical production by NADH dehydrogenase. CancerRes. 43: $4543-4551$

56. Doroshow JH (1983) Effect of anthracycline antibiotics on oxygen radical formation in rat heart. Cancer Res. 43: 460-472

57. Doroshow JH and Davies KJ (1986) Redox cycling of anthracyclines by cardiac mitochondria. II. Formation of superoxide anion, hydrogen peroxide, and hydroxyl radical. J. Biol. Chem. 261: 3068-3074

58. Sinha BK, Katki AG, Batist G, Cowan KH, and Myers CE (1987) Adriamycinstimulated hydroxyl radical formation in human breast tumor cells. Biochem. Pharmacol. 36: 793-796

59. Boland MP, Foster SJ and O'Neill LA (1997) Daunorubicin activates NF- $\kappa$ B and induces NF- $\kappa$ B-dependent gene expression in $\mathrm{HL}-60$ promyelocytic and Jurkat $\mathrm{T}$ lymphomy cells. J. Biol. Chem. 272: 12952-12960

60. Holtz-Heppelmann CJ, Algeciras A, Badley AD, Paya CV (1998) Transcritional regulation of human FasL promotor-enhancer region. J. Biol. Chem. 237: 44164423

61. Staal FJT, Ela SW, Roederer M, Anderson MT, Herzenberg LA and Herzenberg, LA (1992) Glutathione deficiency and human imunodeficiency virus infection. Lancet 339: 909-912

62. Malorni W, Rivabene MT, Santini MT and Donelli G (1993) N-acetycysteine inhibits apoptosis and decreases viral particles in HIV chronically infected U937 cells. FEBS Lett. 327: 75-78

63. Castedo M, Macho A, Zamzami N, Hirsch T, Marchetti P, Uriel J and Kroemer G (1995) Mitochondrial perturbations define lymphocytes undergoing apoptotic depletion in vivo. Eur. J. Immunol. 25: $3277-3284$

64. Macho A, Castedo M, Marchetti P, Aguilar JJ, Decaudin D, Zamzami N, Girard PM, Uriel J and Kroemer G (1995) Mitochondrial dysfunctions in circulating T lymphocytes from human immunodeficiency virus-1 carriers. Blood 86: 2481 2487

65. Jacobson MD (1996) Reactive oxygen species and programmed cell death TiBS 21: $83-86$

66. Scaffidi CA, Fulda S, Srinivasan A, Friesen C, Feng L, Tomaselli KJ, Debatin KM, Krammer PH and Peter ME (1998) Two CD95 (APO-1/Fas) signaling pathways. EMBO J 17: 1675-1687

67. Nicoletti I, Migliorati G, Pagliacci MC, Grignani F and Riccardi C (1991) A rapid and simple method for measuring thymocyte apoptosis by propidium iodide staining and flow cytometry. J. Immunol. Meth. 139: 271-279

68. Carbonari M, Cibati M, Cherchi M, Sbarigia D, Pesce AM, Dell'Ann L, Modica A and Fiorelli M (1994) Detection and characterization of apoptotic peripheral blood lymphocytes in human immunodeficiency virus-infection and cancer chemotherapy by a novel flow immunocytometric method. Blood 83: 1268-1277

69. Peter ME, Dhein J, Ehret A, Hellbardt S, Walczak H, Moldenhauer G and Krammer PH (1995) APO-1 (CD95)-dependent and -independent antigen receptor-induced apoptosis in human T and B cell lines. Int. Immunol. 7: 18731877 